$\begin{array}{ll}\text { Balkanologie } & \begin{array}{l}\text { Balkanologie } \\ \text { Revue d'études pluridisciplinaires }\end{array}\end{array}$

Vol. $16 n^{\circ} 1 \mid 2021$

Au-delà de la "route des Balkans »: mondes sociaux des circulations

\title{
Rebetiko Neighbourhoods: Musical Encounters and Social Transformations in Drapetsona and Nea Kokkinia, Piraeus
}

Les quartiers du rébétiko : rencontres musicales et transformations sociales à Drapetsona et Nea Kokkinia, Le Pirée

\section{Alexandra Mourgou}

\section{(2) OpenEdition}

Journals

\section{Electronic version}

URL: https://journals.openedition.org/balkanologie/2885

DOI: 10.4000/balkanologie.2885

ISSN: 1965-0582

\section{Publisher}

Association française d'études sur les Balkans (Afebalk)

\section{Electronic reference}

Alexandra Mourgou, "Rebetiko Neighbourhoods: Musical Encounters and Social Transformations in Drapetsona and Nea Kokkinia, Piraeus", Balkanologie [Online], Vol. 16 n 1 | 2021, Online since 01 June 2021, connection on 03 October 2021. URL: http://journals.openedition.org/balkanologie/2885 ; DOI: https://doi.org/10.4000/balkanologie.2885

This text was automatically generated on 3 October 2021.

(c) Tous droits réservés 


\title{
Rebetiko Neighbourhoods: Musical Encounters and Social Transformations in Drapetsona and Nea Kokkinia, Piraeus
}

\author{
Les quartiers du rébétiko : rencontres musicales et transformations sociales à \\ Drapetsona et Nea Kokkinia, Le Pirée
}

Alexandra Mourgou

\section{Introduction}

1 From the nineteenth century until the Interwar period, nation-states were formed progressively out of the multiethnic societies of the former Ottoman Empire. ${ }^{1}$ This process brought about a long period of wars, deportations and mass murders. ${ }^{2}$ During this period, the Greek state expanded geographically and established itself as a nationstate, developing the corresponding ideological mechanisms in order to homogenise the heterogeneous population, consolidate a "European" identity and denounce any oriental cultural elements. ${ }^{3}$ In continuation of the Second Greco-Turkish War (1919-1922), the Treaty of Lausanne was signed (July 1923). The treaty ${ }^{4}$ validated the foundation of two nation-states, Turkey and Greece, and enforced the deportation of Muslims from Greece to Turkey and of Greek Orthodox Christians from Turkey to Greece. ${ }^{5}$

2 The arrival of one and one-half million refugees from Asia Minor (1922-1923), as well as the departure of a vast number of people, provoked major social and urban transformations. ${ }^{6}$ As the port of Piraeus was the main gathering point for the displaced populations, a great number of refugees from Asia Minor settled in its periphery. Social and urban transformations were reflected in all aspects of social life, including musical creation. ${ }^{7}$ Urban popular music in Greece started to develop extensively in the late 
nineteenth century and bloomed particularly during the Interwar period. In several neighbourhoods where refugees settled, a new genre of music flourished, known widely as rebetiko; a term which can invoke many different meanings from musical, social and spatial context. ${ }^{8}$

3 According to Jackson, popular culture is "predominantly urban in character" 9 and reflects metropolitan experience, the transformations of an industrial society and the making of a working class. Rebetiko, as a critical part of the popular culture, is perceived as an ensemble of social practices and experiences that embodies the refugee memory and the process of survival of the impoverished urban populations. This paper studies the relations between the socio-spatial transformations and the evolution of popular music through the investigation of the everyday life in the working-class refugee neighbourhoods, putting into question the context in which the official discourse enlisted repressive mechanisms in order to control and de-construct the culture that emerged from this "dangerous class"10

\section{Methodology}

4 To address this question, we will first focus on the connections between the development of Piraeus in the early twentieth century, the massive settlements of refugees after 1922-1923 and the emergence of renewed urban popular culture. Focusing on two different refugee neighbourhoods, we will highlight the connections between space and culture by analysing the construction and the emergence of cultural practices in different contexts. These examples were selected as two representative cases in which the material and immaterial conditions of the urban and social fabric are characterised by similarities as well as differences. On the one hand, both are characterised by a working class and refugee context, the proximity of industrial and port infrastructures and the presence of a vast number of rebetiko musicians. On the other hand, the ways that memory was given life in the culture(s) that emerged is different, a fact also reflected in the evolution of music. In Nea Kokkinia, refugee memory has been the main core of construction of the interweaving identities in its territory, while in Drapetsona the pre-existence of industrial infrastructure and places of social deviation has marked the identities that emerged before and after the arrival of the refugees. This juxtaposition casts light on the different social and spatial meanings of rebetiko.

5 The present paper brings together interview excerpts and documented testimonies from key informants (musicians, collectors and descendants of musicians). The interviews were conducted between 2017 and 2019 to gather original and transgenerational memories of the everyday practices related to space and music in the selected neighbourhoods. The testimonies presented in this article cast new light on the varying qualities of the neighbourhoods and the ways that music was elaborated in them. They also reveal the constellation of cultural and social identities that collide and coalesce in space and establish the connection between space and music.

\section{Theoretical framework}

6 The research is set within an interdisciplinary theoretical context, wherein the notions of space(s) and place(s) are perceived by a "relational" approach, ${ }^{11}$ in order to explore 
the process(es) and the dialectic relations that emerge in space through time. Following Massey, the idea that "the identity of place - the sense of place - is constructed out of an introverted, inward-looking history based on delving into the past for internalised origins" ${ }^{12}$ is deceiving. On the contrary, it is the result of a constellation of different identities and "can only be constructed by linking that place to places beyond." 13 Moreover, this article perceives the spatiality of the social practices, as they appear in Henri Lefebvre's Critique de la vie quotidienne ${ }^{14}$ and in Doreen Massey's For Space. ${ }^{15}$ Massey's concept of "a global sense of place" is particularly useful. ${ }^{16}$ Considering the relations between different social and cultural identities as a key component of the process through which music was formed, we will attempt to analyse the multiple dimensions of its spatiality, through the recognition of the identities that coexist in it. 17

\section{Spatial and musical encounters}

\section{Piraeus as a social and cultural melting pot}

7 In 1834, Athens was proclaimed the capital of the new nation-state. In 1835, Piraeus was declared its official port and an independent municipality. The period from the midnineteenth until the beginning of the twentieth century was transitional as Piraeus was growing into a modern industrial port city. The marine and railway networks, developed during the later nineteenth century, turned Piraeus into a nodal point among the ports of the Ottoman Empire, Black Sea, Alexandria and the Western Mediterranean, ${ }^{18}$ and connected the city with rural Greece and other important urban centres in the Balkans. ${ }^{19}$ The industrial zone of Piraeus was formed gradually in the northwestern part of the city and expanded parallel to the railway axes and towards the western coast of the port, at the area of Drapetsona. ${ }^{20}$

The construction of a railway turned out to be one of the determinant factors in the socio-spatial polarisation of the city, as the railway tracks functioned as a heavy barrier that divided the city in two parts: the southeastern, which was the commercial part and place of residence for the privileged social classes, and the northwestern, which gradually evolved into the place of industrial development and residence for the disadvantaged classes. ${ }^{21}$ In the wake of the First Greco-Turkish War (1897), the Balkan Wars (1912-1913) and immigration to the United States in the early twentieth century, great numbers of people moved successively from the countryside to Piraeus. All those who were "not welcome" settled on the northwestern side, close to the rail tracks and the industrial zone, forming the first working-class neighbourhoods of Piraeus (e.g. Agios Dionysios, Maniatika, Kaminia, Agia Sofia, Ipapanti). ${ }^{22}$ As people from very different origins, and from all over Greek territory, were brought together in Piraeus, its newly formed working-class neighbourhoods became a regional melting pot, smelting heterogeneous cultural elements in a context of modernisation. ${ }^{23}$ 
Image 1. The working-class neighbourhoods and railway of Piraeus in the early twentieth century

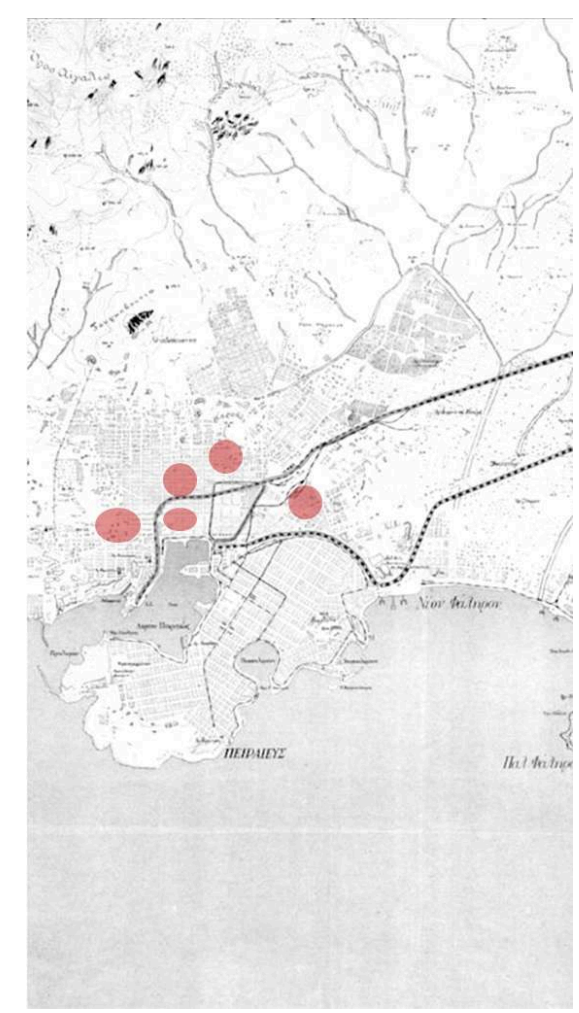

Source: Hellenic Military Geographical Service, edited by Alexandra Mourgou.

9 The working class of Piraeus during this period cannot be considered a rigid social structure. Any attempt to classify these impoverished peoples strictly and objectively according to their position in economic production would collide with reality of social and economic fluidity. The luckiest worked in industry, but the majority only worked occasionally and informally in conditions of insecurity: atypical labour, piece-work, child labour, peddlers, street vendors. ${ }^{24}$ Marginality was widespread in Piraeus, with beggars and other port dwellers living under extremely harsh conditions. Progressively, certain activities that the authorities wished to keep invisible (such as prostitution houses and hashish dens) started to concentrate in specific urban zones outside the socially advantaged part of the city. ${ }^{25}$

The majority of the refugees from Asia Minor first arrived in the port of Piraeus (1922-1923), where they temporarily stayed in camps, until some of them were transferred to other cities or neighbourhoods. A big part of them settled permanently in Piraeus's periphery, forming refugee neighbourhoods, such as Nea Kokkinia, Drapetsona, Keratsini, Ikonio, Anastasi and others. ${ }^{26}$ The refugees' installation stirred a new urban reality with particularities of class and culture. It contributed to a new wave of development and of industrial growth. Gradually, Piraeus evolved into the biggest working-class city of Greece. Displaced, impoverished, vulnerable and disadvantaged, many refugees joined the homeless population, became occasional workers, or occupied semi-illegal jobs typical of the impoverished social strata. ${ }^{27}$

The interaction between the refugees and the previous inhabitants ${ }^{28}$ brought out new identities in a certain space. The rearrangement of everyday life within these neighbourhoods combined the poverty of the present with the cultural heritage of their past. People from very different backgrounds were forced to share the same 
spaces, with only a few common points: Orthodox religion, Greek nationality and the indigent living conditions. ${ }^{29}$ Through this encounter, popular culture bloomed, fertilised from the refugee element within the specific socio-spatial conditions. ${ }^{30}$

Image 2. Refugee neighbourhoods of Piraeus

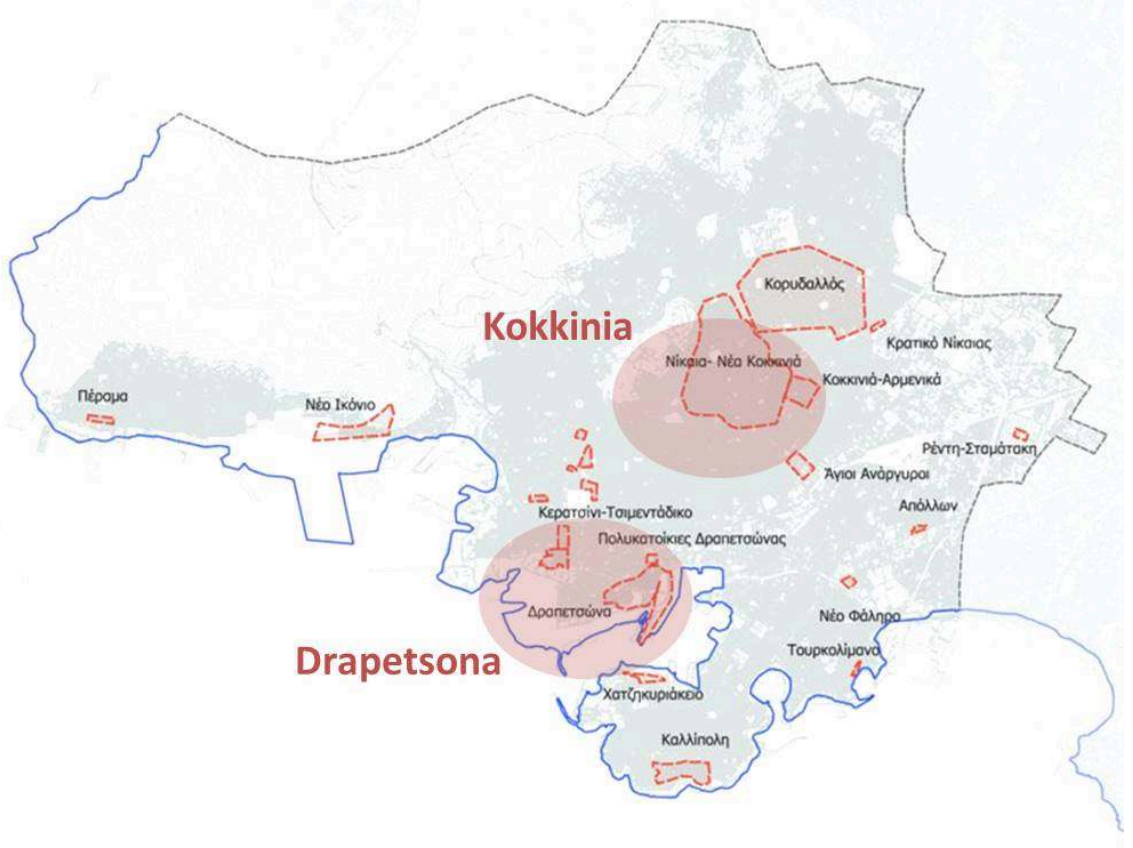

Source: Urban Environment Laboratory, N.T.U.A., edited by Alexandra Mourgou.

\section{Urban popular music as a bearer of multiethnic culture(s)}

Musical blending was a wide and vivid phenomenon in the multiethnic port cities of the Eastern Mediterranean. The development of a distinctive musical genre during the late nineteenth and early twentieth century was the outcome of a sophisticated interpretation of popular oral musical forms which originated from the populations that had moved into the cities. ${ }^{31}$ This idiom was the result of an encounter of Turkish, Greek, Arab, Armenian and other linguistic and musical elements, distanced from the nationalist ideals of the period that were tearing down the multiple cultural identities. 32

The profession of the musician in the modern sense of the term existed, and demanded high standards of mastery and technique. Due to the urban and social networks, music was spread, loved and played within the lower and middle strata of the port cities of the Eastern Mediterranean and the Balkans, Athens and Piraeus included, from the late nineteenth century. Discography during this period was very limited, leaving the oral tradition as the principal means of diffusion. The café aman $^{33}$ was the main place where people gathered to perform and enjoy these songs. Due to its immaterial hypostasis, the musical performance was a sophisticated process, whose role was central in the urban social life. ${ }^{34}$ 
"Smyrneiko," which literally means "from Smyrna/the way of Smyrna." The term is widely used to describe the wide range of popular music with direct and indirect modal references, which was the main repertoire of the popular music in the ports of the Eastern Mediterranean and the Balkans. ${ }^{35}$ As Pennanen and Andrikos point out, despite the fact that the majority of the musicians were coming mainly from the urban spaces of the Ottoman Empire and relocated in Greece after the population exchange, they were characterised as representatives of Smyrneiko. This nomination emerged from the emblematic image of Smyrna in the fantasy of the Neo-Hellenic milieu. ${ }^{36}$ Said another way:

They (musicians from Smyrna) were such masters, so well educated in music that whatever song they played was as if they put it in a honey jar and made it sweet. ${ }^{37}$

Image 3. "Ta Politakia" is a group of musicians from Asia Minor very characteristic of the musical idiom of Smyrna

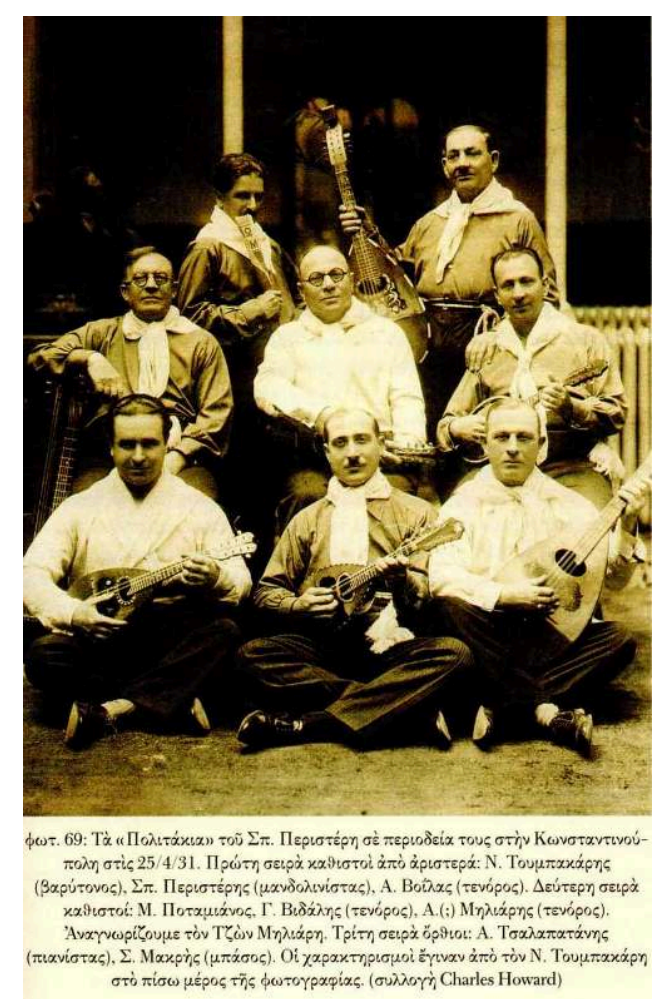

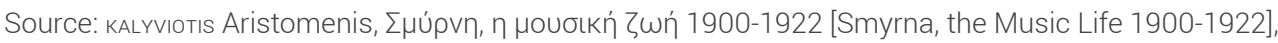
Athens, Music Corner \& Tinella, 2002, p. 127.

During the later nineteenth and the early twentieth century, a musical idiom blossomed in Piraeus, related to the café aman repertoire. Henceforth called "premature rebetiko," ${ }_{38}$ this idiom was much rougher, without melody ornaments, and it was performed mainly on bouzouki and [Greek] baglamas. ${ }^{39}$ The bouzouki was a very popular instrument, associated with the long-standing (rural and urban) tradition and it was taught through everyday practice. As these populations relocated in the capital at the end of the nineteenth century, they brought it with them. ${ }^{40}$

Premature rebetiko reflects the multiple forms of cultural interweaving that took place within the poor strata of Piraeus. This idiom has been associated from researchers with the culture of the underworld and the tradition of rebellion. In fact, the places where 
this idiom blossomed were often characterised by social deviation and entrenchment, like the hashish dens and the prisons. Although these places are different, they share certain similarities as far as social networks and practices are concerned. Since the beginning of the twentieth century, premature rebetiko was popular among the café aman musicians, partly included in their repertoire and diffused beyond the places of entrenchment. Another important point in the diffusion of the premature rebetiko, was the migration to the U.S.A. where many recordings took place at the turn of the century. ${ }^{41}$

\section{Rebetiko as a process of socio-spatial transformation(s)}

17 Rebetiko is a signifier that can host many signifieds in different historical contexts. ${ }^{42}$ As a music genre, it embodies techniques from both tonal and modal systems. It maintains the oriental philosophy as far as the ornate structure of melody is concerned, with a careful use of occidental harmony. As far as rhythms are concerned, the influence of traditional music of Asia Minor, the Balkans and the Aegean islands is evident. It is related to a great part of the popular songs of the late nineteenth and early twentieth century, mostly, but not only, the café aman repertoire and the premature rebetiko. ${ }^{43}$

Rebetiko is considered as the music of the people who relocated to Athens and Piraeus and formed the popular strata of the city. Coming from different places, they were seeking a shared code of expression and communication; a "language" based on the development of common symbols that produce common meanings in the context of an aggregation of shared social practices. Therefore, it is the funnel of a variety of other musical idioms with different historical, social and musical features, whose origins can be identified mainly in the homelands of these people. A wide range of rebetiko songs are forged by the conditions of urbanisation, the state of being a refugee and the emergence of discography. These songs started to be registered from the late nineteenth century in the urban centres of the Eastern Mediterranean such as Izmir and Istanbul, and were mainly capitalised from discography in Greece during the Interwar period..$^{4}$

19 Although the term rebetiko appeared in the beginning of the twentieth century, its early usage "seems inextricably linked to non-musical characteristics," ${ }^{55}$ like clothes and manners. Thus, rebetiko in this paper is perceived as an assemblage of social practices and common experiences, related to music creation and performance and to the refugee memory that emerged from a nexus of social relations developed in the neighbourhoods of the poor strata of the Interwar period. The contribution of the refugees to the evolution of urban popular music was undeniable. The encounter of musicians, refugees or not, in the taverns, café aman and the hashish dens of Piraeus made them share common spaces of living and places of performance on all spatial scales. The previous inhabitants and the refugees shared the same conditions of underemployment, social exclusion, poverty and insecurity. Music, as a means of survival, reveals how the premature rebetiko and the café aman repertoire interwove fruitfully and stirred out a new way of making things.

Through discography, the oral urban musical tradition was reproduced in a more sophisticated way and widely diffused, especially during the 1930s. During this period, the discography in Athens was led by companies such as His Master's Voice, Columbia and Odeon. ${ }^{46}$ The registration of the songs was determinant for the music itself, as the 
songs should fit the discography standards: a specific duration, commerciality, lyrics and music approved from the direction of the company. ${ }^{47}$

Music also responded to pressure and penalisation by the authorities. Stratification of social classes in the city, cultural identities that co-exist, and the constitution of the nation state are the three main factors of urban marginality ${ }^{48}$ Certain social practices related to popular culture and the places where rebetiko was performed were targeted by the authorities for legal deviation, thus triggering the repressive mechanisms. The censorship enforcement of the 4th of August Regime was the peak of this process: it prohibited, criminalised and persecuted modality and the oriental musical ornament, as well as the music of the hashish dens after $1936-1937 .{ }^{49}$ The stigmatisation of the oriental elements aimed to flatten the multicultural identities of the music, to canalise it in a context of strict national cultural norms and to marginalise whatever deviated from the nationalist representation of the "Greek European Identity." The persecution of not only the genre but the musicians as well, was intense..$^{50}$

\section{Nea Kokkinia: Place(s) of refugee memory in a working-class context}

\section{Refugee memory and place-making}

At the end the nineteenth century, the area of Nea Kokkinia was sparsely inhabited. At the southeastern part, there was a lime kiln, while other spaces in the area were used as waste dumps. During this period, the industrial zone of Piraeus expanded alongside the railway and the first working-class settlements of Piraeus were formed. Around 1915, Armenian refugees from the Ottoman Empire were added to these settlements. Developed in the southeastern part of Nea Kokkinia, they formed its periphery. The majority of the inhabitants were working in the developing industrial zone of Piraeus. ${ }^{51}$ The following testimony of an Asia Minor refugee reveals the geographical limits before the formation of the refugee settlements in Nea Kokkinia:

\footnotetext{
After our arrival at the port, you know, Piraeus, and after the decontamination, we were taken - on foot, of course -, to a bare mountain called Vokos, with houses on its slope. On the other hand, to this point, it was empty. We arrived, not to digress, in a place that had tents and some houses that were built with bricks and it was called Kokkinia. ${ }^{52}$
}

The urbanisation of Nea Kokkinia started to intensify after the arrival of the refugees. Contrary to the situation in Drapetsona, institutional organisations for refugee settlements played a relevant role from the very first years. The Fund for Refugee Assistance (FRA) (established for temporary relief), the Refugee Settlement Commission (RSC) (that became the urban planner for the refugee settlements on Athens' peripheries), as well as the Ministry of Social Welfare (MSW) had a great impact in the construction of social refugee housing. In the years between 1923 and 1928, Nea Kokkinia's population rose to $33,201 .^{53}$

In Nea Kokkinia, the collective refugee memory of the Ottoman past marked every aspect in their relocation process. ${ }^{54}$ "'There,' is an important part of the overall narrative, which returns as a decisive reference; it encodes memory, nostalgia, a measure of comparison with 'here'; and it is a place associated with loved ones and familiar practices." ${ }^{55}$ For the uprooted refugees, their homeland's geography remained 
a reference on a symbolic level and was used as a way of self-orientation in the unknown new urban space, through the creation of familiar symbolic representations. The search of "ritualistic connections" ${ }^{56}$ reflected the gradual transformation of the unknown space(s) into familiar place(s). ${ }^{57}$ Progressively, the neighbourhoods of Nea Kokkinia were woven into small communities: small-scale socio-spatial entities ${ }^{58}$ based on the existing social networks sharing an emotional and symbolic significance related to the place..$^{59}$ The discriminations between refugees, according to their specific homelands, as well as local stereotypes were often used in everyday language. For example, those from Smyrna were often considered to be sociable, progressive, frivolous; revellers, scrappers, gossipers; with "light morals." Those from the interior of Asia Minor were considered serious, peaceful, "half-witted." Those from Istanbul were considered as "better than the others," regardless of their social position. Those from the southern coasts of the Black Sea were considered stubborn, but also very serious and smart. ${ }^{60}$ Their organisation in the new settlements was based mostly, but not absolutely, on the organisation of their homelands (Agios Nikolaos, Osia Kseni, Agios Georgios, Krini [Germanika], Chalkidona, Armenika [Neapoli], Peykakia). ${ }^{61}$

Agios Nikolaos was considered as the most prestigious neighbourhood and was mostly inhabited by people from Istanbul; the "aristocrats of Nea Kokkinia" who were the first to get access to the social housing. Refugees coming mostly from the area of the Black Sea settled in Osia Kseni. It was considered as a quiet neighbourhood, inhabited by diligent workers full of pride and stubbornness. Krini took its name from the homonymous suburb of Smyrna in Asia Minor, known as Krini (in Greek) and Çeşme (in Turkish), and there settled refugees from the area of Smyrna. It was considered a loud neighbourhood where people liked to fight a lot, to dance and sing, and where the women were infamous for their morals. ${ }^{62}$ As Giorgis Papazoglou recalled:

When they (the previous inhabitants) saw that only women (refugees) came, they thought that they would take their men. When my mother went to buy a small broom, the vendor almost kicked her out, so that she wouldn't steal her husband. ${ }^{63}$

Despite the institutional planning of refugee settlements by FRA, RSC and MSW, living conditions were still characterised by poverty, miserable housing and persistent social and spatial exclusion. The personal and collective struggle for survival was the main issue of everyday life. Nonetheless, social life in Nea Kokkinia was characterised by intense sociability, extroversion and an intense participation of women in social life. Manners, social relationships and ethics reflected cultural heritage, while the poverty and indigence of the present informed the rest. ${ }^{64}$ As Leontidou underlines, "even this confined internal space was no problem, because everyday life was extended to patios and yards, which also served as laundries and workshops, to doorsteps and pavements for informal socializing, to empty plots which became playgrounds for the children, and to piazzas, which converted public space into common space". ${ }^{65}$

Narratives of local dwellers confirm this analysis of sociability amidst poorly constructed dwellings:

In this neighbourhood, where I grew up, people were more than friends, they were brothers. The neighbourhood was built that way, all the houses and the dwellings. [... ] When the river overflowed, the water spilled and everything went into the shanties and that was a tragedy. ${ }^{6}$

It was a degraded area. There were old houses, the refugee houses. But then, the refugees started to rebuild them. They were working hard, and they liked nice things [...] we had our neighbourhoods, and one neighbour to another, they might 
have had fights, but they cared for each other. [...] In the afternoons everybody was coming outside of the house, chewing their sunflower seeds as they were talking. ${ }^{67}$

\section{Urban popular music as an aspect of the culture of survival} previous experience and skills in musical performance, they managed to assume important positions in the recording companies and to determine the aesthetics of the gramophone. ${ }^{73}$ Nea Kokkinia became famous for its rich music life, which emerged from the everyday life. Giorgis Papazoglou describes how the songs and life recalled each other:

Wait, [you would notice] there's a Smyrneiko song.

[Singing] Little girls with ribbons, socks with oulama ${ }^{74}$

The little girls are wearing, going to work.

Short, short hair, keeping their cap low

The little girls are wearing, going to the looms. ${ }^{75}$

[speaking] [You see] When [girls] were on their way in the morning, you knew where they were going. If they had short hair, they were going to the textile industry ... [they] kept [the hair] short so they would not be grabbed - one had been killed in Nea Ionia ${ }^{76}$ : her hair was grabbed by the power loom and her head was taken off. [...] When you saw the other guy walking in blue, you knew that he was a mechanic, a turner. And you could guess one's destination based on his clothing. ${ }^{.7}$

32 It is notable that Giorgis Papazoglou characterises this song as "Smyrneiko." The melody does bring to mind the café aman repertoire, but the lyrics describe a typical 
image of men and women of the working class in Nea Kokkinia. This fact reveals the emergence of the song through the everyday life and unfolds the interweaving multiple identities in the places of Nea Kokkinia, in the sense that the memory of "there" (Smyrna) was consolidated in the everyday struggle of "here" (Nea Kokkinia).

Image 4. Female workers in the textile industry

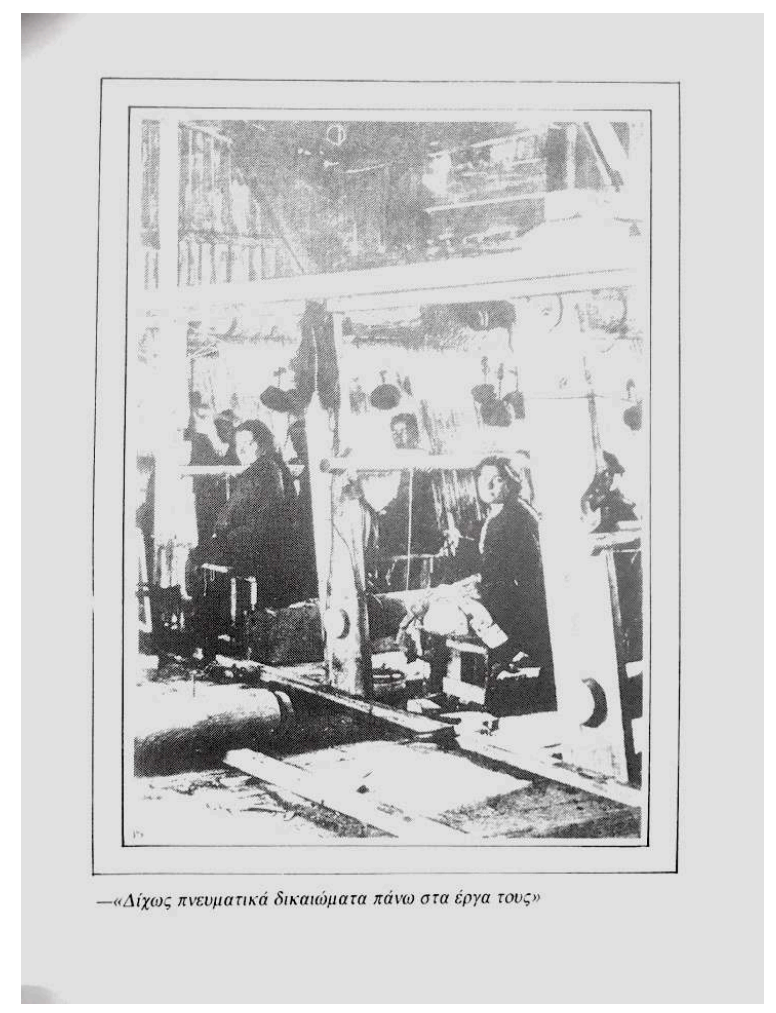

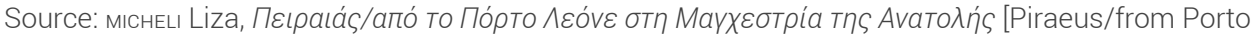
Leone to the Oriental Manchester], Athens, Galateia, 1993.

As music was a formative element of the everyday life and practices, the nightlife of Nea Kokkinia was described as overwhelming. The little taverns and the café aman were the spaces where music from Asia Minor relocated and met the local musical elements: "In the evening, you can see people everywhere. The roofs of the little taverns turn spontaneously into dancing floors. [...] The instruments never stop playing the music, the glasses are always full of beer and the waiters never stop running [...] [Nea Kokkinia] is a loud refugee city that knows how to seize the night. [...] Nightlife in Kokkinia is the richest of all refugee settlements". ${ }^{78}$

There were many taverns in Kokkinia. But what I really enjoyed was this particular tavern across the street from our house. In this tavern, they were having many feasts. There was a lot of fun, and every afternoon the ouzo drinkers, the card players, the dice players, the drunks, every person from this cast was gathering there. And they were coming from other neighbourhoods as well. They came from Agia Sofia, from the Anastasi, from Hatzikyriakio, from Tabouria [...], and it was a neighbourhood where the music flourished. [...] Music was bringing all these people together. Music is a thing of love. Do you understand? This thing was bringing them close, Alexandra. [...] Markos, and Batis and Keromytis, and Genitsaris, [...]. And I want to tell you that my neighbourhood was like a dream. ${ }^{79}$ 
Places of deviation were not missing from the nightlife of Nea Kokkinia. The encounter of music and deviant social practices was one of the important aspects of the popular entertainment of the neighbourhood.

Kokkinia was the best place for entertainment. There was everything you wanted! Can you imagine what I'm telling you? Anything! I'm telling you this, Alexandra, anything. Do we need to talk about the hard stuff now? We don't. [...] Women, you could find women, anything you wanted. [...] No one could hide, because the neighbourhood was an enclave. ${ }^{80}$

The "hard stuff" that Stelios refused to tell me about included drugs:

The hashish was circulating freely [in Nea Kokkinia]. The most famous hashish dens were next to the police stations. ${ }^{81}$

Not far from Nea Kokkinia, another rebetiko neighbourhood was gradually formed. Similar but also very different, Drapetsona seems to host a vast number of social, spatial and musical contexts that reveal some of the aspects of rebetiko.

\section{Drapetsona: Place(s) of urban and music outcast(s)}

\section{The making of a refugee neighbourhood among the industries, the hashish dens and the prostitution houses}

The image of Drapetsona in the mid-nineteenth century was very different from what it became during the Interwar period. Full of rocky slopes and creeks, the settlement was scarcely inhabited; a pesthouse functioned on its coast and there were a few slums on the east side, along the Bay of Kremmydarou, where sailors and hashish smokers gathered. Despite its proximity to Piraeus, Drapetsona remained invisible due to its topographical features. At the end of the nineteenth century, the cemetery of Piraeus was transferred to Drapetsona. In 1876, the municipality of Piraeus adjudicated the construction of the Vourla - official prostitution houses - in an attempt to limit prostitution. However, there were fewer efforts to combat the development of a large sphere of other deviant and illegal activities and professions practiced by the impoverished population, such as smugglers, scammers, hashish dens owners. ${ }^{82}$ Because, as another informant explained,

Certainly, this [the establishment of Vourla] does not mean the absolute control of the crime. Prostitution comes together with the underworld: Loverboys, pimps, junkies, outcasts... a whole world whose action starts when the night falls. ${ }^{83}$

Moreover, many unofficial sex workers continued working, outside of the institutional borders of Vourla. They were working in all the small available spaces, like the narrow alleys between the storage rooms of the machining workshops (lamarinadika).

They went there between the metal sheets, the machineries, and the "work" was done. And when you saw a tin with fire between the metal sheets you knew that some prostitute was working [...]. There, worked the illegal girls, the Kalnderimitzoudes (street walkers). ${ }^{84}$

At the turn of the century, the industrial zone of Piraeus was expanded into the territory of Drapetsona with the construction of large modern industrial and harbour infrastructures along the coast. Among numerous industrial units and factories, the most important were the Vasiliades Shipyard (and the permanent built tanks of the 
Port of Piraeus Organisation OLP, 1906), the Fertilizers Factory (1909) and Hercules Cements (1911). ${ }^{85}$ Settlement followed:

We came to Drapetsona when I was a seven-year-old kid. [...] Anyone who hasn't crossed the bridge doesn't know what Drapetsona means. Because here were the factories [...] I worked in the Fertilizers Factory when I grew up. ${ }^{86}$

The first settlement cores of Drapetsona, Vourla and Kastraki (near Kremmydarou, where the shipyards were installed), were formed gradually. Due to the proximity with the harbour, the development of the industrial zone and the invisibility from the city of Piraeus, Drapetsona was the main reception area for the most vulnerable social strata that migrated to the capital - mostly from Peloponnese and the Greek islands. They settled in dwellings with tiny makeshift wooden structures, close to each other, without floor and covered by tin roofs. ${ }^{87}$ The inhabitants were, in their vast majority, artisans, unskilled labourers, wandering unemployed or occasional workers in the industry, as well as people whose survival depended on deviant or illegal professions. ${ }^{88}$ In Drapetsona, urban marginality was systematically reproduced. ${ }^{89}$

Drapetsona was the cradle for prisons, songs and hashish dens. An important element of the popular urban music was the smoking of hashish, either in hashish dens or in remote caves near the sea. The smoking of hashish among the poorest social classes was inextricably tied with their need to escape from the roughness of their everyday life. ${ }^{90}$

Piraeus here. Port. The world is misplaced. Some of them were playing cards, others were turning to women and others were smoking. I started smoking at Foukas. [...] Those who worked in the ports acquired the habit and spread it to the workers and to anyone who sought to forget. ${ }^{11}$ 


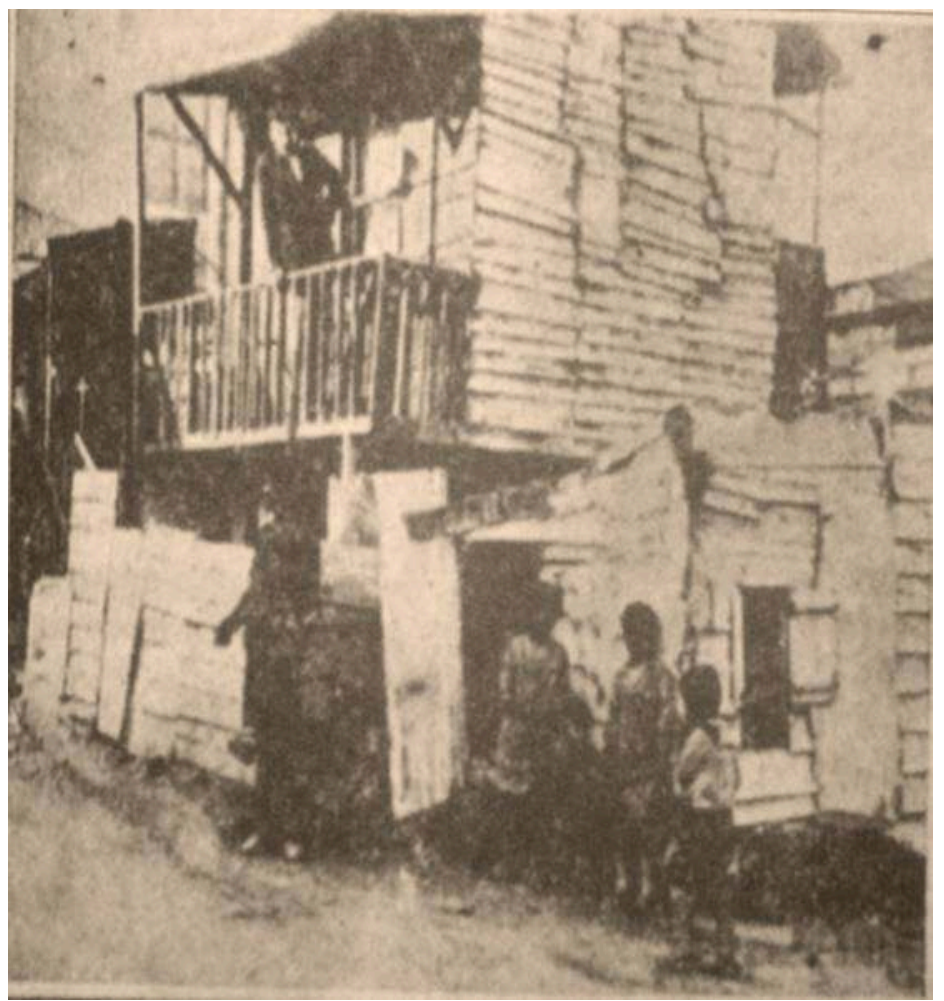

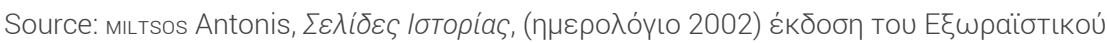

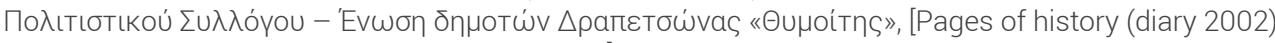
edition of the Association of citizens "Thymoitis"], Drapetsona, 10.2001.

After the arrival of the refugees, the whole region was transformed into an improvised camp. Motivated by the working possibilities in the industrial and portal zone - as new industrial units were created and the existing ones were enlarged - the underprivileged displaced population started to settle in any available space of the residential core of Drapetsona, forming self-built settlements. Contrary to other districts, like Nea Kokkinia, the absence of central planning for refugee housing was a decisive factor in the socio-spatial transformation of Drapetsona. During the 1930s, the tents gave their place to more permanent constructions, mostly slums and dwellings. ${ }^{92}$ Regardless of the lack of institutional support and the miserable housing conditions, the inhabitants of Drapetsona were far from indifferent to their homes' upkeep: they painted their houses and they planted small pots with flowers. ${ }^{93}$

The population of Drapetsona was characterised by intense mobility. Once they had the opportunity, they would move to other neighbourhoods. However, the social features of the neighbourhood remained remarkably stable. People either chose to reside in this area - due to its characteristics - or they adopted those during their stay. ${ }^{94}$ Some of the main conditions through which the survival culture emerged had been industrial labour, the housing conditions in slums and dwellings, the relation of the neighbourhood with prostitution and the hashish dens as well as the broader social exclusion. Prostitution expanded with the arrival of the refugees and was connected with the survival process of the impoverished strata. In this context, the origin of the population - refugees or previous inhabitants - was of minor importance. ${ }^{95}$

But when most of the [male refugee] population stayed apart, prisoners, killed, [...]

how would women work, when they had two, three or four kids and their men had 
been killed or left behind? How would they cope? How many of them would work as washers, or in factories? [...] In order for her (a woman's) children not to die, she had to go into prostitution, what worse could possibly happen to her? And the hashish dens owners around Vourla took advantage of this. [...]. What was the den? A shack and it had toilets next to it. Barbed wire with flowers all around, with a corridor that went to the toilet. They set up two or three sliding windows and called the refugee girls: "come to the window." He would knock on the window, give a buck, and the girl would take out her butt, so that they couldn't see her face. These were called "window brothels". ${ }^{96}$

\section{From the entrenchment to the diffusion}

The consumption of hashish was a practice widely disseminated and shared among the previous inhabitants and the refugees. Hence, they gradually started to share the places where this was practised. Within these entrenched places, the hashish dens and the caves of Drapetsona, the premature rebetiko was mooted with the refugees' musical idiom and matured through the filter of common experiences: the social and spatial marginality and the struggle for survival. The encounter in the hashish dens came along with the practice of music to the point that the ownership of baglamas (small instrument) was considered evidence of hashish consumption. Markos Vamvakaris who used to work as a skinner in the slaughter house was honest:

After this carnage [his work], you understand how longing I was taking the road to the den. [...] Everybody knew that I was a hashish user from the baglamas; this was an instrument that you had to hide under your jacket, in the pocket. ${ }^{97}$

Urban popular music was not practised only in the entrenched places. On the contrary, it was an important part of everyday life in Drapetsona. Apart from the hashish dens, there were many small taverns, shops, workshops of musical instruments and cafés:

There were a lot of music instrument houses. [...] And this place was a music instrument house. He used to make santours, violins. [...] Afterwards, several instrumental players from Pontos moved in Kokkinia [...]. We also had lyres and kementzedes [small violins in Turkish]. ${ }^{98}$

The refugees relocated with their songs and their traditions. The extrovert way of living and their cosmopolitism did not abandon them. The encounter of the refugees' musical culture with the music practices of the previous inhabitants under the situation of poverty and hard work formed an ensemble of common experiences through which the sentiment of common and collective identity was cultivated. ${ }^{99}$

7 In 1934, the Famous Quartet of Piraeus ${ }^{100}$ had its first professional performance at the tavern Konstantopoulos in Drapetsona. This performance is considered a turning point because it marked the integration of these musicians and their repertoire into the sphere of professionals. Moreover, at the symbolic level, this quartet was an ensemble of refugees (Anestos Delias and Stratos Payoumtzis) and people who had moved to Piraeus from the Greek islands (Markos Vamvakaris and Giorgos Batis) and reflects the cultural medley among the inhabitants, in and out of the entrenched places. 


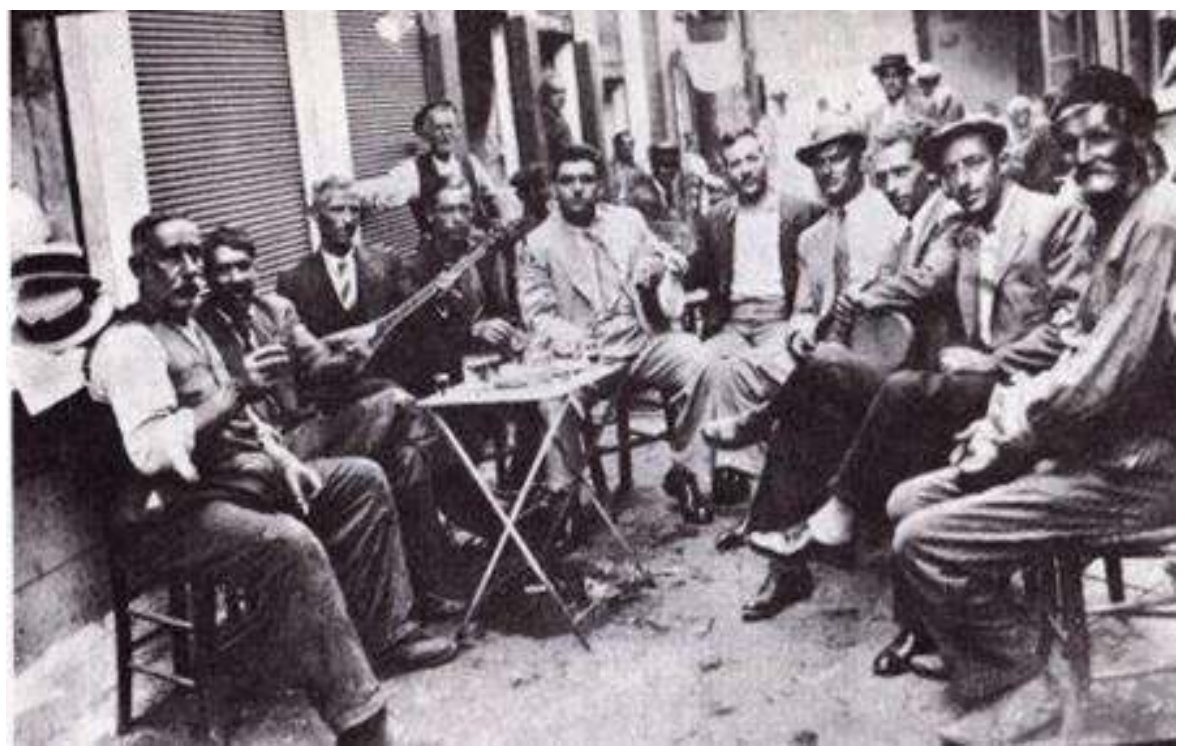

Source: petropoulos Elias, Rembetika. Songs from the Old Greek Underworld, Athens, Kedros, 1991, p. 424.

Giorgos Batis is one of the most typical examples that unfolds the constant struggle for survival, through the practice of multiple professions. Batis was one of the senior musicians of Piraeus (born in 1890). The style of the senior musicians of the period of premature rebetiko was maintained through his recordings. In 1925, he owned a "dancing school" in Drapetsona along with café-hashish dens; he sold medications for callus and dental issues; he worked as a street vendor, a peddler and more. As a musician, he worked randomly at cafés and taverns. Schorelis mentioned that the "old school guys" used to call him the "King of Piraeus" and remembered him as a person who played the baglamas - hidden always in his jacket - in the streets of Piraeus. In his songs, he described images of the everyday life of the fragile strata, such as their professions, their places of entertainment, their deviant spaces (like caves and hashish dens), as well as the life in prison. ${ }^{101}$

Meanwhile, not far from the Konstantopoulos, there were several other taverns where the professional refugees were performing. As Stellakis Perpiniadis emphatically informs us, there was a huge difference between the customers of these places. The following testimony enhances the different aspects of rebetiko:

I was playing music with Kavouras, and in a junkyard nearby, there was Markos, Batis, Stratos and Delias.... The junkyard was full. Full. But... there, it was a different kind of people [...]. We were working with collars, with collar people let's say, [...]. The "Aristocracy". ${ }^{102}$

With the advent of discography, music diffused in every corner of the neighbourhoods and thus a new profession emerged, the grammophonitzis: a person that was wandering around, putting rebetiko songs on the gramophone.

Once, I visited the "University" of Drapetsona [...]. An undercover cop approached me and said: "Not only do we let you play these songs without arresting you, but you put them on the gramophone and you defy us." 103

The existence of a constellation of different social and cultural identities in Drapetsona led to a gradual osmosis and elaboration of common identities, whose features were the 
extrovert character and the cosmopolitanism brought by the refugees' homelands combined with the culture of a working class living under indigent conditions, "in and out" of the social margins. ${ }^{104}$ Through the interwoven conditions of the neighbourhood, a system of solidarity developed, that led to the formation of common consciousness with social and political impact. While during the 1910s and 1920s Drapetsona was considered a morally dangerous neighbourhood, during the 1930s, it was considered a politically dangerous one. Paraphrasing Jackson, slums, dwellings and refugee houses "were regarded as 'parent' of the disorder and the nursery of vice." ${ }^{105}$ The presentation - in the official discourse - of Drapetsona as a dangerous and inaccessible neighbourhood is related to the attempt of the authorities to connect rebetiko with crime, as well as the attempt of the authority to castigate the working class. ${ }^{106} \mathrm{As}$ Markos Vamvakaris underlines,

The popular [urban song] was influenced by the hearts of poor working workers. ${ }^{107}$

\section{Conclusion}

This article attempted to enhance the connections between space and music by focusing on two proximate but different neighbourhoods of rebetiko. In Drapetsona and Nea Kokkinia, the memory of displacement encountered the process of survival in a context of intense urbanisation, industrialisation and nation-building. Through this encounter, popular culture was formed as an assemblage of social practices and shared experiences. The selected interview excerpts and testimonies brought together the multidimensional aspects of music and social life, unfolded the varying qualities of the neighbourhoods and their music, revealed the cultural and social identities and established the connection between the making of the working class, the formation of refugee settlements and the evolution of urban popular music. Nea Kokkinia was formed through a complex of socio-spatial transformations which reflected the memory of the refugees' homelands, their interaction with the non-refugee population, while Drapetsona was formed as a place of urban outcasts where a specific culture blossomed through the interweaving of music, prostitution and poverty in deviant spaces.

Rebetiko was established as a critical aspect of social life and identity making, despite the repressive policies that affected it, describing its places as dangerous and inaccessible. We assume that its link with deviation has been underlined systematically in the context of a general castigation of the impoverished strata, the working class and their social practices. Through the articulation of these multiple identities, the popular culture of the working-class and refugee neighbourhoods blossomed and diffused beyond any social, spatial or temporal limit. As a bearer of the multiethnic past and the unfavourable conditions of living of the impoverished populations, rebetiko became the voice of slums and dwellings: a voice that echoes loudly even nowadays. 


\section{NOTES}

1. The author would like to thank Dina Vaiou (Professor Emerita, N.T.U.A.), Yannis Vlahopoulos and Georgina Papada for their assistance in preparing this manuscript for publication.

2. MAZOWER Mark, The Balkans: From the End of Byzantium to the Present Day, London, Orion Publishing, 2002.

3. SAID Edward W., Orientalism, New York, Pantheon Books, 1978.

4. According to the Treaty of Lausanne, the Muslims of Western Thrace and the Greek Orthodox population of Istanbul were exempt from the population exchange. HIRSCHON Renée, The Heirs of the Greek Catastrophe, New York, Berghahn Books, 1998.

5. CLOGG Richard, "Nation Building, the 'Great Idea' and National Schism 1831-1922," in Richard Clogg, A Concise History of Greece, Cambridge, Cambridge University Press, 2013, p. 46-97.

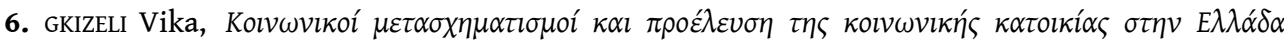
1920-1930 [Social Transformations and the Origin of Social Housing in Greece 1920-1930], Athens, Epikairotita, 1984.

7. NETTL Bruno, Study of Ethnomusicology, Champaign, University of Illinois Press, 2005.

8. ANAGNostou Panagiota, "Did You Say Rebetiko? Musical Categories, their Transformation, and their Meanings," Journal of Social History, vol. 52, $n^{\circ}$ 2, 2018, p. 283-303.

9. JACKSON Peter, Maps of Meaning, London, Unwin Hyman, 1989, p. 78.

10. Ibid., p. 89.

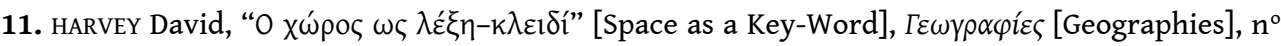
10, 2005, p. 21-42 (23).

12. MASSEY Doreen, “A Global Sense of Place,” Marxism Today, June 1991, p. 25-29 (26).

13. Ibid., p. 29.

14. LEFEBVRE Henri, Critique de la vie quotidienne, Paris, L'Arche, 1977.

15. MASSEY Doreen, For Space, London, Sage, 2005.

16. MASSEY, "A Global Sense of Place," op. cit.

17. Ibid.

18. HASTAOGLOU-MARTINIDIS Vilma, "The Cartography of Harbor Construction in Eastern Mediterranean Cities: Technical and Urban Modernization in the Late Nineteenth Century," in Biray Kolluoglu, Meltem Toskoz (eds), Cities of the Mediterranean. From the Ottomans to the Present Day, London, I.B. Tauris, 2010, p. 78-99.

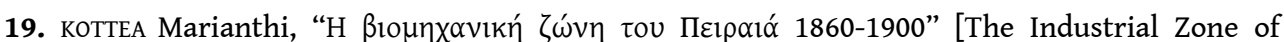

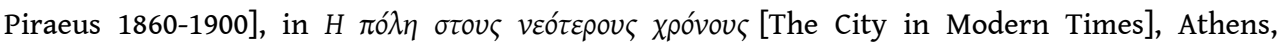
Association des Études Néohelleniques, 2000, p. 115-123.

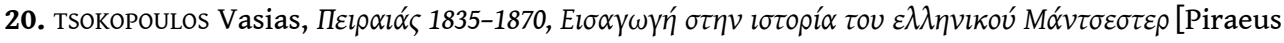
1835-1870, Introduction to the History of Greek Manchester], Athens, Kastanioti, 1984.

21. Ibid.

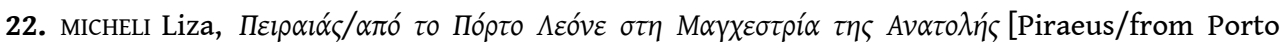
Leone to the Oriental Manchester], Athens, Galateia, 1993.

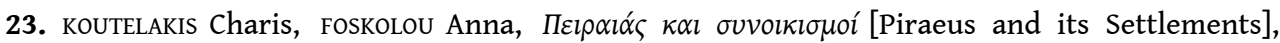
Athens, Vivliopoleio tis "Estias," 1991.

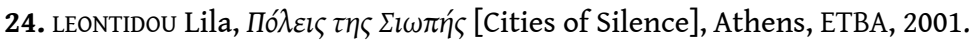

25. Ibid.

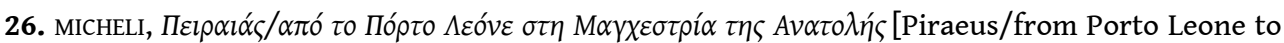
the Oriental Manchester], op. cit.

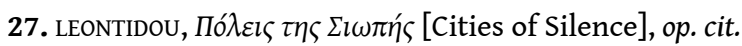


28. In several cases I am referring to the non-refugee population as previous inhabitants in order to enhance the difference between them and the refugees from Asia Minor, without considering them as homogenous.

29. HIRSCHON, The Heirs of the Greek Catastrophe, op. cit.

30. JACKSON, Maps of Meaning, op. cit.

31. коккоNIS Georges, La question de la grécité dans la musique néohellénique, Paris, Association Pierre Belon, 2008.

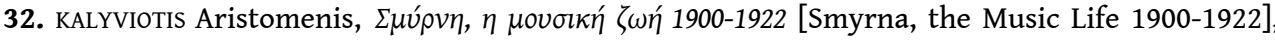
Athens, Music Corner \& Tinella, 2002.

33. An oriental version of the French café chantant, in which blossomed the urban popular musical idiom of the Eastern Mediterranean. The café aman was the most common space of social entertainment in the port cities of the Eastern Mediterranean. See: CHATZIPANTAZIS Theodoros, $T \eta \varsigma$

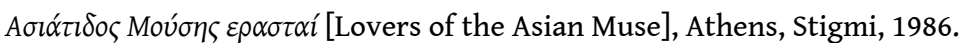

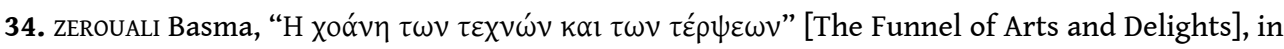

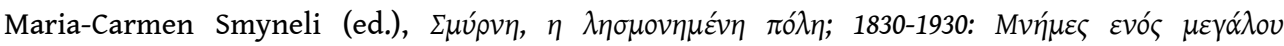

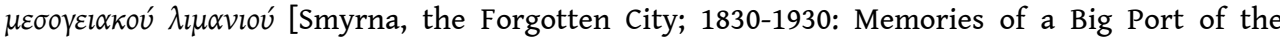
Mediterranean], Athens, Metaichmio, 2008, p. 169-190.

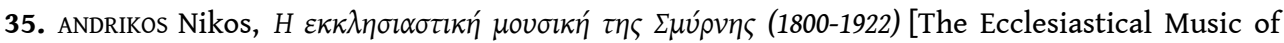
Smyrna (1800-1922)], Athens, Topos, 2015.

36. PENNANEN Risto Pekka, 1997, "The Development of Chordal Harmony in Greek Rebetika and Laika Music, 1930s to 1960s," The British Journal of Ethnomusicology, Ethnomusicology Forum, vol. 6, 1997, p. 65-116.

37. Testimony of Giorgis Papazoglou, [personal archive].

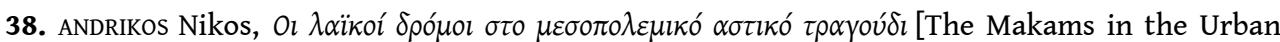
Popular Music of Interwar], Athens, Topos, 2018.

39. A very tiny type of bouzouki, very different from Turkish baglama. KOUROUSIs Stavros, Aтó tov

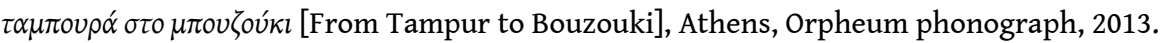

40. PENNANEn Risto Pekka, "The Organological Development and Performance Practice of the Greek Bouzouki," in Risto Pekka Pennanen, Westernisation and Modernisation in Greek Popular Music, Tampere, University of Tampere, 1999, p. 119-185.

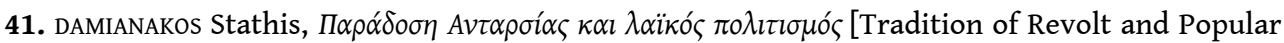
Civilisation], Athens, Plethron, 2003.

42. LACLAU Ernesto, Emanicipation(s), London and New York, Verso, 1996.

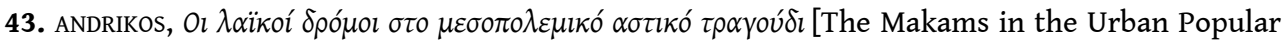
Music of Interwar], op. cit.

44. Ibid.

45. ANAGNOStou, "Did You Say Rebetiko?," op. cit. p. 3.

46. ноLST Gail, Road to Rembetika, Limni Evoias, Denise Harvey, 2011.

47. TRAGAKI Dafni, Rebetiko Worlds, Newcastle, Cambridge Scholars Publishing, 2007.

48. WACQUANT Loïc, "Urban Outcasts: Stigma and Division in the Black American Ghetto and the French Urban Periphery," International Journal of Urban and Regional Research, vol. 17, $\mathrm{n}^{\circ} 3,1993$, p. 366-383.

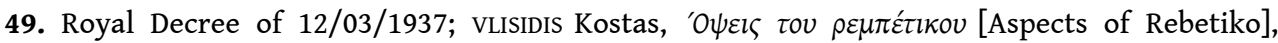
Athens, ekdosis tou eikostou protou, 2004.

50. Ibid.

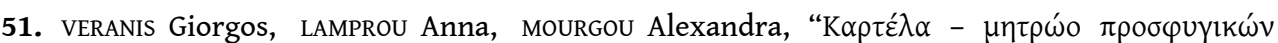

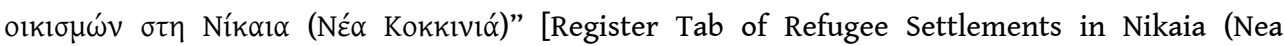

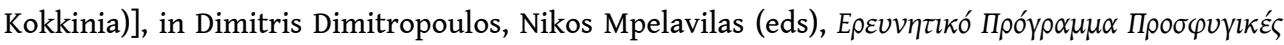




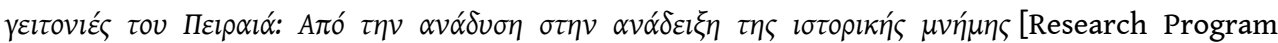
Refugee Neighbourhoods of Piraeus: From Emergence to Designation of Historical Memory], Athens, N.H.R.F.-N.T.U.A., 2018, p. 153-160.

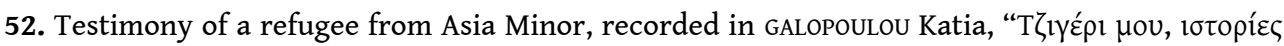

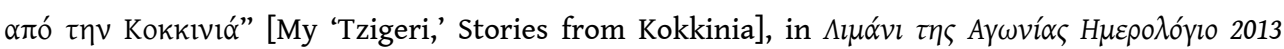

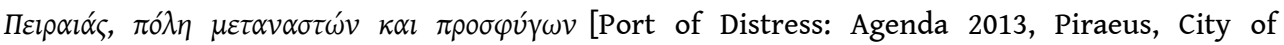
Immigrants and Refugees], Piraeus, Dimiourgiko Ergastiri, 2013, p. 32-38 (35).

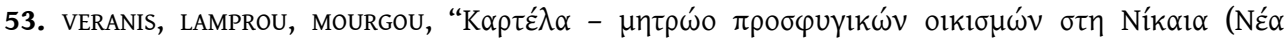
Kokkıvıó)" [Register Tab of Refugee Settlements in Nikaia (Nea Kokkinia)], op. cit.

54. HIRSCHON, The Heirs of the Greek Catastrophe, op. cit.

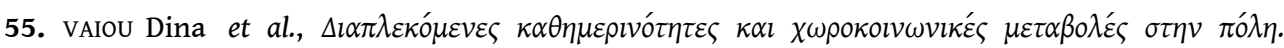

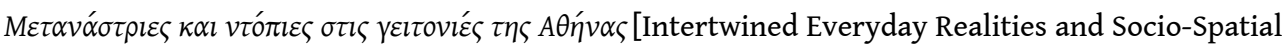
Transformations in the City. Immigrants and Locals in the Neighbourhoods of Athens], Athens, LPress \& N.T.U.A., 2007, p. 12. The punctuation has been adjusted in translation.

56. MASSEY, “A Global Sense of Place," op. cit., p. 28.

57. HIRSCHON, The Heirs of the Greek Catastrophe, op. cit.

58. LEFEBVRE, Critique de la vie quotidienne, op. cit.

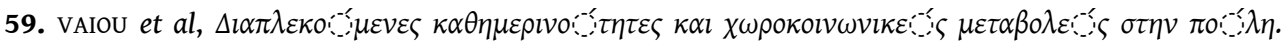

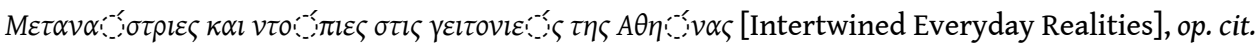

60. HIRSCHON, The Heirs of the Greek Catastrophe, op. cit.

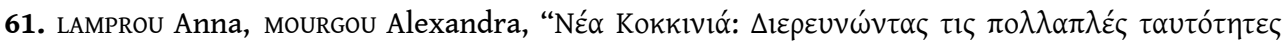

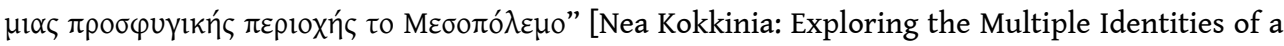

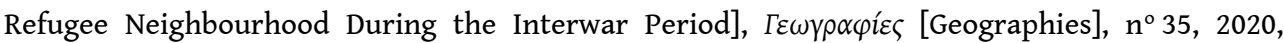
p. 146-155.

62. HIRSCHON, The Heirs of the Greek Catastrophe, op. cit.

63. Testimony of Giorgis Papazoglou, [personal archive].

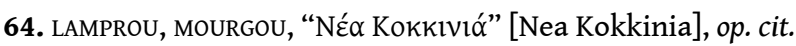

65. LEONTIDOU Lila, "Slums of Hope," Athens Social Atlas, April 2017, online: https:// www.athenssocialatlas.gr/en/article/slums-of-hope/ (accessed in July 2021).

66. Testimony of Stelios Vamvakaris, [personal archive].

67. Testimony of Eleni Perivola, [personal archive].

68. LEONTIDOU Lila, "Slums of Hope," Athens Social Atlas, April 2017, online: https:// www.athenssocialatlas.gr/en/article/slums-of-hope/ (accessed in July 2021).

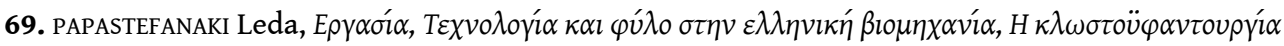

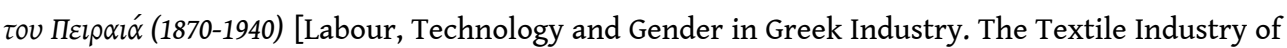
Piraeus (1870-1940)], Herakleio, Crete University Press, 2009.

70. Testimony of Stelios Vamvakaris, [personal archive].

71. Ibid., p. 246.

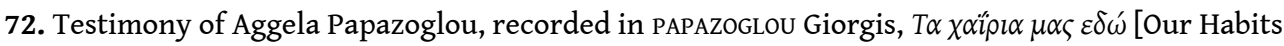
Here], Athens, Eptalofos, 2003, p. 104.

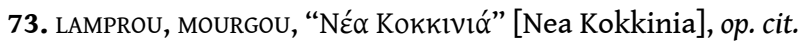

74. A thick sock hem, but also a genre of improvised singing.

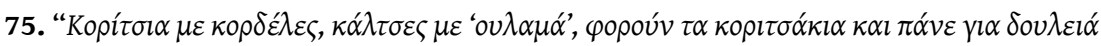

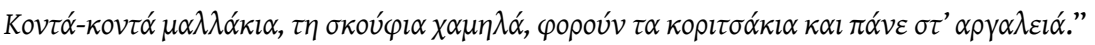

76. Another working-class neighbourhood of Athens.

77. Testimony of Giorgis Papazoglou, [personal archive].

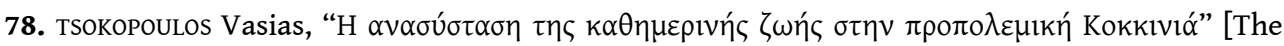
Reconstruction of Everyday Life in Kokkinia Before the Second World War], in Evi Prousali (ed.), 


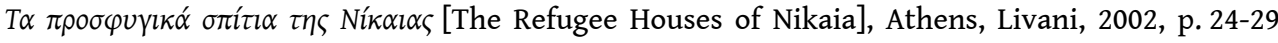
(28).

79. Testimony of Stelios Vamvarkaris, [personal archive].

80. Ibid.

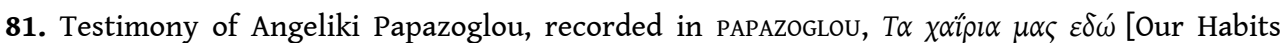
Here], op. cit. p. 50.

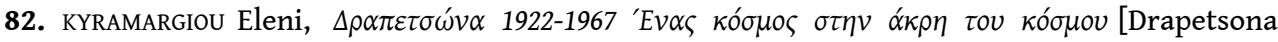
1922-1967 A World at the Edge of the World], Athens, N.H.R.F, 2019.

83. Testimony of Vasilis Pisimisis, [personal archive].

84. Ibid.

85. CHEIRCHANTERI Georgia, "Transformation in the Wider Industrial Coastal Region of Saint George, Western of Piraeus Port in Athens," IOP Conference Series: Materials Science and Engineering, vol. 471, nº 10, 2019, p. 1-10.

86. Testimony of Stavrikos Papavramidis, [personal archive].

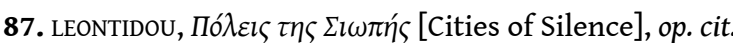

88. KYRAMARGIOU, $\Delta \rho \alpha \pi \varepsilon \tau \sigma \omega ́ v \alpha$ 1922-1967 [Drapetsona 1922-1967], op. cit.

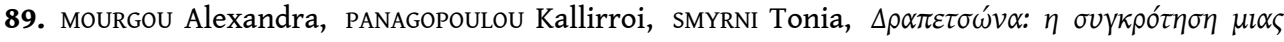

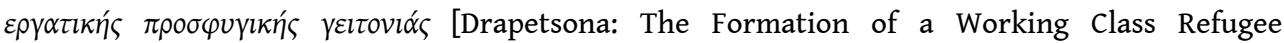
Neighbourhood], Athens, Ypsilon, 2017.

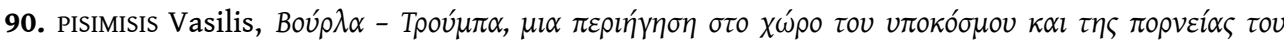

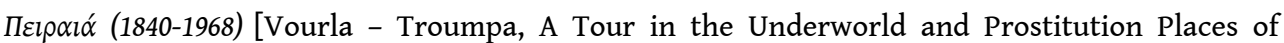
Piraeus (1840-1968)], Piraeus, Tsamantaki, 2010.

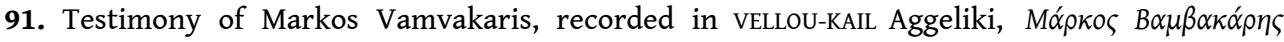

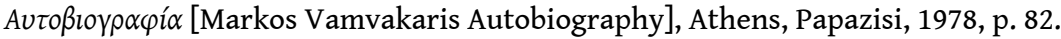

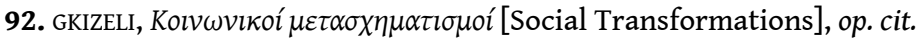

93. MOURGOU, PANAGOPOULOU, SMYRNI, $\Delta \rho \alpha \pi \varepsilon \tau \sigma \omega ́ v \alpha$ [Drapetsona], op. cit.

94. KYRAMARGIOU, $\Delta \rho \alpha \pi \varepsilon \tau \sigma \omega ́ v \alpha$ 1922-1967 [Drapetsona 1922-1967], op. cit.

95. Ibid.

96. Testimony of Vassilis Pisimisis, [personal archive].

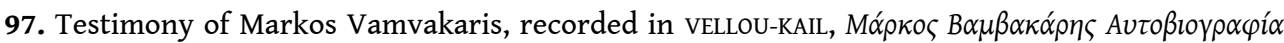
[Markos Vamvakaris Autobiography], op. cit., p. 147-148.

98. Testimony of Stavrikos Papavramidis, [personal archive].

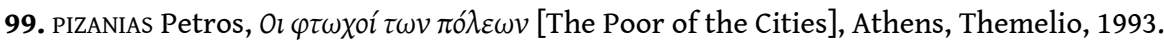

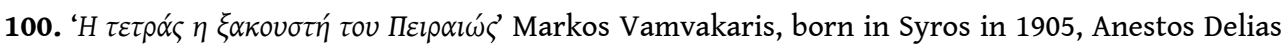
born in Smyrna in 1914, Stratos Payoumtzis born in Ayvalık in 1904, Giorgos Mpatis from Methana in 1885. TRAGAKI, Rebetiko Worlds, op. cit.

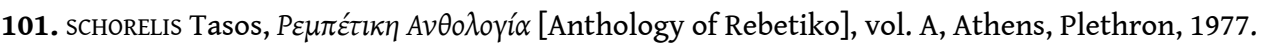

102. Testimomy of Stellakis Perpiniadis, recorded in the interview of Stellakis Perpiniadis (1975?), musician from Smyrna who relocated to Piraeus as a refugee, Archive of ERT, online: https://www.youtube.com/watch?v=W4wVlfxrOpY (accessed in July 2021).

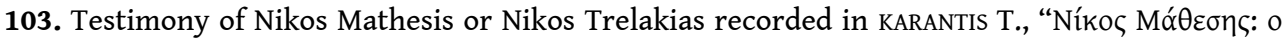

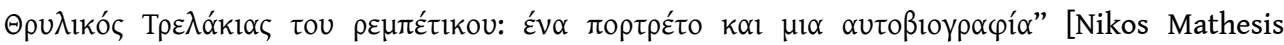
Legendary Crazy of Rebetiko: A Portrait and an Autobiography], from the Rebetiko Forum, 2010,

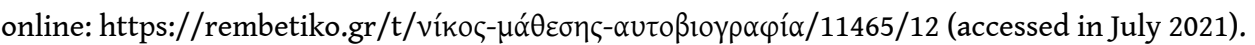

104. MOURGOU, PANAGOPOULOU, SMYRNI, $\Delta \rho \alpha \pi \varepsilon \tau \sigma \omega ́ v \alpha$ [Drapetsona], op. cit.

105. JACKSON, Maps of Meaning, op. cit. p. 101.

106. KYRAMARGIOU, $\Delta \rho \alpha \pi \varepsilon \tau \sigma \omega ́ v \alpha$ 1922-1967 [Drapetsona 1922-1967], op. cit. 


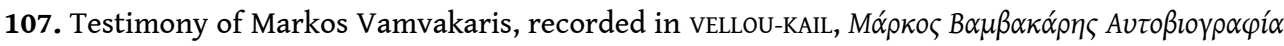
[Markos Vamvakaris Autobiography], op. cit., p. 169.

\section{ABSTRACTS}

During the Interwar period, the port of Piraeus was the main migration and refugee gathering point in Greece. In its refugee and working-class neighbourhoods, a genre of music blossomed, widely known as rebetiko. Attempting to achieve a socio-spatial interpretation of rebetiko, we shall explore connections between the evolution of urban popular music and the places where it flourished. We shall focus on two different examples, Drapetsona and Nea Kokkinia, in order to cast light on the way rebetiko - as a part of the popular culture - emerged from a nexus of social practices and experiences of the working-class refugee strata.

Pendant l'entre-deux guerres, le port du Pirée a été le pôle d'attraction principal de flux migratoires et de réfugiés en Grèce. Dans les quartiers ouvriers et refugiés, un genre musical a émergé, le rébétiko. Cet article a pour but d'élaborer une interprétation socio-spatiale du rébétiko en explorant les connexions entre l'évolution de la musique populaire urbaine et les lieux de son épanouissement. On se focalisera sur deux quartiers différents, Drapetsona et Nea Kokkinia, afin de mettre en lumière comment le rébétiko - en tant qu'élément important de la culture populaire - a émergé à travers un tissu de pratiques sociales et d'expériences au sein de couches sociales fragiles.

\section{INDEX}

Mots-clés: entre-deux-guerres, quartiers ouvriers et réfugiés, musique populaire, rébétiko, Drapetsona, Nea Kokkinia, Pirée

Keywords: Interwar period, working-class refugee neighbourhoods, popular music, rebetiko, Drapetsona, Nea Kokkinia, Piraeus

\section{AUTHOR}

\section{ALEXANDRA MOURGOU}

National Technical University of Athens and Université Paris 1 Panthéon-Sorbonne alexandramourgou[at]gmail.com 